\title{
MORPHOLOGICAL PLASTICITY IN THE RHIZOME SYSTEM OF SOLIDAGO GIGANTEA (ASTERACEAE): COMPARISON OF POPULATIONS IN A WET AND A DRY HABITAT
}

\author{
Z. BотTA-DuKÁT \\ Institute of Ecology and Botany, MTA Centre for Ecological Research, H-2163 Vácrátót, \\ Alkotmány u. 2-4, Hungary; E-mail: botta-dukat.zoltan@okologia.mta.hu
}

(Received 1 July, 2016; Accepted 5 August, 2016)

This study was motivated by the fact that although the plasticity of its above-ground organs is obvious in natural conditions and there are many data on the plasticity of Solidago's rhizome system in glasshouse experiments, there are no data on below-ground plasticity under natural conditions. We compared the morphology of rhizomes in two, contrasting habitats. We found that rhizome system responded to environmental conditions: in the dry habitat, ramets developed more but shorter rhizomes compared to the wet habitat. The decrease in rhizome length can be explained by the decrease in the size of above-ground organs, but the increase of rhizome number cannot. The most important regulating factor of rhizome growth is probably its mechanical restriction by the root biomass of other species.

Key words: clonal morphology, goldenrod, Hungary, invasive, ramet, rhizomatous plant

\section{INTRODUCTION}

Morphological plasticity is the ability of a species to change the shape and size of its organs when grown under different environmental conditions. This phenomenon is well known in plants, for example the morphological differences between sun-grown and shade-grown individuals of a particular species. This feature is so peculiar in some free-floating aquatic plants that different "growth forms" of a particular species are often scarcely recognisable as belonging to the same species (Ashton and Mitchel 1989). The high morphological variability allows a species to compete for a wide range of habitats (e.g. Ashton and Mitchel 1989, Shorina and Smirnova 1985).

There are many clonal plants among the most successful plant species including dominant species of several habitats and successional stages (Callaghan et al. 1992, Prach and Pyšek 1994, Sebsen and Thorne 1985), widespread 
weeds (Leakey 1981) or invasive species (Balogh et al. 2003, Pyšek 1997, Thompson 1991). Some clonal species follow strict constructional rules (e.g. Bell 1979, Noble et al. 1979), while others can alter their clonal growth (see review in Kroon and Hutchings 1995) in response to their abiotic environment (e.g. Slade and Hutchings 1987a, b), intensity of competition (e.g. Hartnett and Bazzaz 1985a) or type of competitor (e.g. Schmid and Bazzaz 1992).

At fine scale, the plastic placement of ramets can increase the proportion of ramets in favourable microsites (Sutherland and Stillman 1988), but the optimal strategy depends on the spatial and temporal predictability of the environment (Oborny 1994). At coarse scale, plasticity yields differences in species demography across communities.

Solidago gigantea is a successful invasive species in large regions of Europe (Weber 1998). In western Hungary it occurs in different habitats from the edges of swamps to dry grasslands (Botta-Dukát 1994, Botta-Dukát and Dancza 2008). Plasticity of the above-ground organs is obvious. In wet habitats, $S$. gigantea forms monodominant patches, where shoot height, shoot density and the proportion of flowering shoots are high. In dry habitats, it co-occurs with other species (primarily different grasses); shoot height, shoot density and the proportion of flowering ramets are low. There is little information on the plasticity of rhizome system. Although previous studies, based on glasshouse experiments, reported that the rhizome system of Solidago species responded to environmental conditions (Hartnett and Bazzaz 1985a, b, Schmid and Bazzaz 1990, 1992), we have only little information about its importance in natural conditions (Alpert 1995).

Therefore, our study aims at answering the following question: Is there any plasticity in the geometry of Solidago gigantea rhizome system in natural conditions? Two sites were chosen to represent two typical communities, where Solidago occurs: edges of swamps and dry grasslands.

Coleman et al. (1994) pointed out, that size of the whole plants has to be considered when studying plasticity in size of organs. Thus, we asked whether plasticity in rhizome number and rhizome length could be interpreted as a consequence of different ramet size in the two sites.

\section{MATERIALS AND METHODS}

\section{The studied species}

Solidago gigantea Ait. is a rhizomatous perennial of North American origin (Botta-Dukát and Dancza 2008, Weber 1998). It appeared in the Carpathian Basin about 150 years ago (Moesz 1909). Since then it spreads quickly (Dancza and Botta-Dukát 2000), and it is considered nowadays as one of the most important invasive plant species in Hungary (Török et al. 2003). Accord- 
ing to definitions of Richardson et al. (2000) Solidago gigantea is a transformer, because in favourable habitats it forms a large, dense, monodominant patches and destroy the original vegetation.

Its rhizome growth is sympodial; shoots develop from the axillary bud of the rhizomes (Fig. 1), and new rhizomes are initiated at the base of the stems (Almádi et al. 1997). The above-ground portion of ramets dies in OctoberNovember, and their daughter rhizomes remain dormant until the following spring. Contrary to the congeneric Solidago altissima, whose rhizome connections persist for up to five years (Cain 1990), we did not find rhizomes older than two years. Only sister ramets were connected through their common mother ramet, and no other interconnections occurred. At the time of study, there were two generations of rhizomes: rhizomes, which developed in the previous year and now connect the sister ramets (below they will be called old rhizomes), and rhizomes, which developed in that year (below they will be called new rhizomes).

\section{Study sites}

Two significantly different habitats were chosen to this study: a dry site with low density of Solidago and a wet site with high density of Solidago.

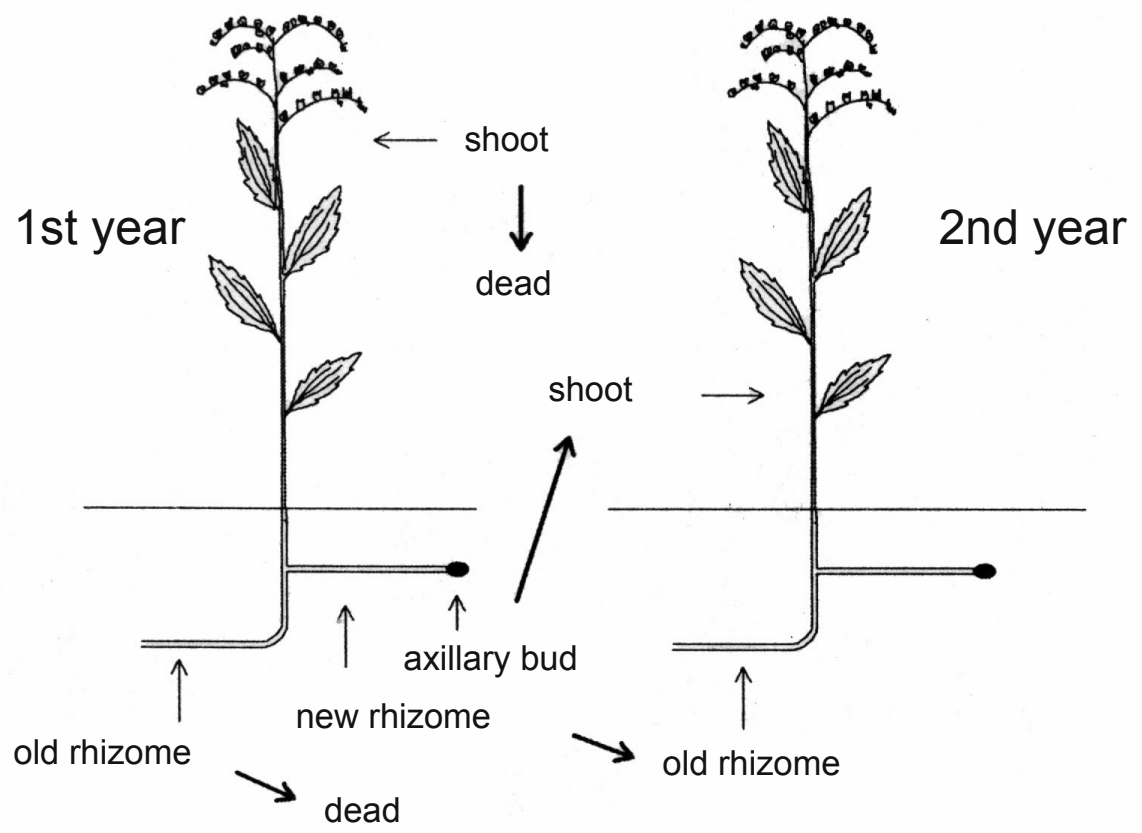

Fig. 1. Vegetative reproduction of Solidago gigantea (bold arrows indicate ontogeny) 
Table 1

Some important features of Solidago populations in the two studied sites

\begin{tabular}{lcc}
\hline & Dry site & Wet site \\
\hline Shoot density $\left(\right.$ shoot $/ \mathrm{m}^{2}$, average $\left.\pm \mathrm{SD}\right)$ & $74.8 \pm 4.65$ & $145.6 \pm 7.89$ \\
Shoot height $(\mathrm{cm}$, average $\pm \mathrm{SD})$ & $102.2 \pm 19.84$ & $134 \pm 31.96$ \\
Proportion of flowering shoots $(\%)$ & 21.9 & 33.3 \\
\hline
\end{tabular}

Both sites were located near Keszthely, in the Kis-Balaton region of the Balaton-felvidék National Park (Hungary). The region is mostly covered by wetland vegetation (e.g. reed and sedge communities). At higher elevations, there are sand dunes with steppe vegetation (Szabó et al. 1998). The dry site was such a sand steppe at about $108 \mathrm{~m}$ a.s.l. Its dominant species were Festuca rupicola, Carex hirta and Botriochloa ischaemum. The wet site was situated about $50 \mathrm{~m}$ from here at about $105 \mathrm{~m}$ a.s.l. Due to lower elevation the availability of water was significantly higher here. The vegetation represented an ecotone between sand steppe and the swamp. In this zone, Solidago gigantea formed monodominant stands, where no other species occurred.

In the dry site, we assume that the major limiting factors are lack of water and nutrients. Roots of co-occurring species create a dense mat in the soil at the depth, where Solidago rhizomes run. This suggests that they compete for water and nutrients. Limitation by the shortage of light was probably negligible since the Solidago density was low (Table 1) and the co-occurring species were shorter than Solidago (height of co-occurring species was $20-40 \mathrm{~cm}$, height of Solidago was $80-100 \mathrm{~cm}$ ).

In the wet site, the water and soil nutrients were ample and the density of Solidago shoots was rather high. Therefore we assume that here the most important limiting factor was the light.

\section{Sampling and data analysis}

To characterise the sites we used shoot density, shoot height and proportion of flowering shoots. Shoot density was counted in 20 plots of $0.5 \mathrm{~m} \times 0.5$ $\mathrm{m}$ before destructive sampling. The shoot height was measured and number of flowering shoots was counted in the shoots excavated for the study of rhizome system. The differences in shoot density and shoot height were tested by Mann-Whitney test (Zar 1999). The proportions of flowering shoots in two sites were compared by $\mathrm{G}^{2}$-test (Sokal and Rohlf 1981).

In the end of August 1999, in both sites all shoots were excavated from about at $2 \mathrm{~m}^{2}$ area. The architecture of rhizome system of Solidago gigantea is intermediate between "compact" and "spreading" type (Schmid and Bazzaz 
1987). It means that this species does not form monoclonal patches but different genets intermingle. On the basis of this fact, the excavated shoots probably belong to several genets. In that time the rhizome growth probably had not finished yet (Werner et al. 1980). However, after fruiting, when the rhizome growth has been finished, shoots easily separate from the below-ground part of ramet, therefore the whole ramet cannot excavated. This earlier sampling date probably does not cause a problem, because there were no phenological differences between sites and in a previous study we had got the same differences between sites based on rhizomes developed in the previous year and rhizomes developed in the year of study harvested in July (Dancza I. and Botta-Dukát Z., unpublished data).

At the border of the excavation area, the rhizome system of the shoots became damaged considerably. Therefore, these shoots were excluded from the subsequent analysis. The 150 and 137 ramets were involved in the analysis in the wet and dry site, respectively. The complete rhizome systems (the connected sister ramets and their new rhizomes) could not be excavated in the dry site. Therefore we measured only the new rhizomes.

To investigate the degree of plasticity, geometry of rhizome systems was compared between sites. The geometry of rhizome systems was characterised by the number of new rhizomes and relative position of their apical bud.

It is important that daughter ramets will devel-

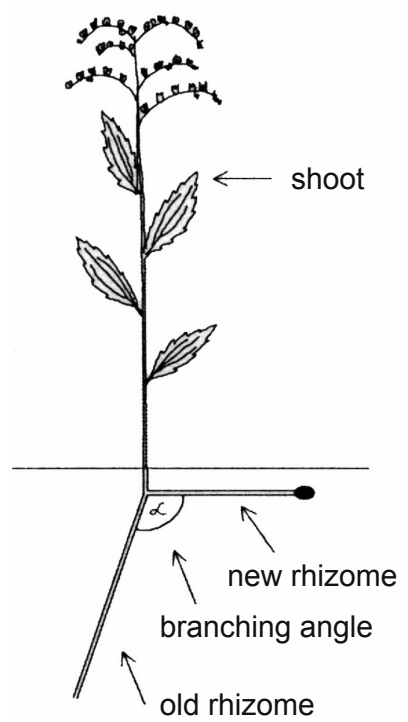

Fig. 2. Definition of branching angle op from the apical buds of the new rhizomes. It means that number of new rhizomes determines the possible number of daughter rhizomes and position of apical buds determines the position of daughter ramets.

Number of new rhizomes was counted in each excavated ramets. Ramets were categorised according to the number of rhizomes developed from their basal part. The shoots with four or more rhizomes were merged into one category to satisfy the assumptions of the test.

In each new rhizome, two variables were measured: length and branching angle (angle between new and old rhizomes; Fig. 2). These two parameters describe unambiguously the position of a daughter ramet relative to its mother.

The apical bud of some rhizomes broke down during excavation. From the statistical point of view, it means that rhizome length is a right-censored data. Therefore, we applied two 
non-parametric tests that are often used in survival analysis: log-rank test and Gehan-Wilcoxon test (Pyke and Thompson 1986). The distributions of branching angle were compared by Watson's U²-test (Zar 1999).

In another analysis, the shoots were divided into two height classes by splitting at average in each site. The two classes were compared within the two sites separately. By this way, relatively tall and suppressed, relatively short shoots were compared in each site disregarding the average shoot size of sites. The same tests were performed between classes as used earlier in the between-site comparison. This let us separate the effect of size from the effect of habitat differences.

\section{RESULTS}

\section{Comparisons between sites}

Comparison of the two sites showed that the density of Solidago was smaller (Mann-Whitney $\mathrm{U}=5.00 ; p<0.001$ ), the shoots were shorter (MannWhitney $\mathrm{U}=4431 ; p<0.001$ ) and the proportion of flowering shoots was lower $\left(\mathrm{G}^{2}=4.7 ; p=0.03\right)$ in the dry site (Table 1$)$.

The distributions of rhizome numbers were significantly different in the two sites $\left(\mathrm{G}^{2}=59.56 ; p<0.001\right)$. In particular, the proportion of ramets with only one daughter rhizome was higher, and the proportion of ramets with three or more daughter rhizomes was lower in the wet site (Fig. 3).

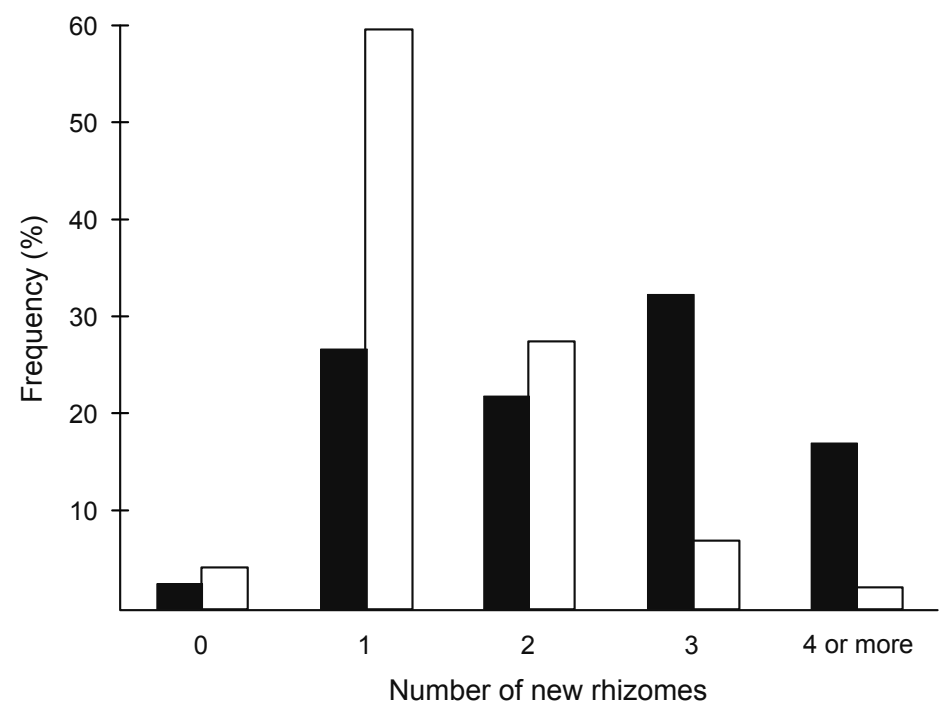

Fig. 3. Histogram of the rhizome numbers in dry (filled bar) and wet sites (empty bar) 


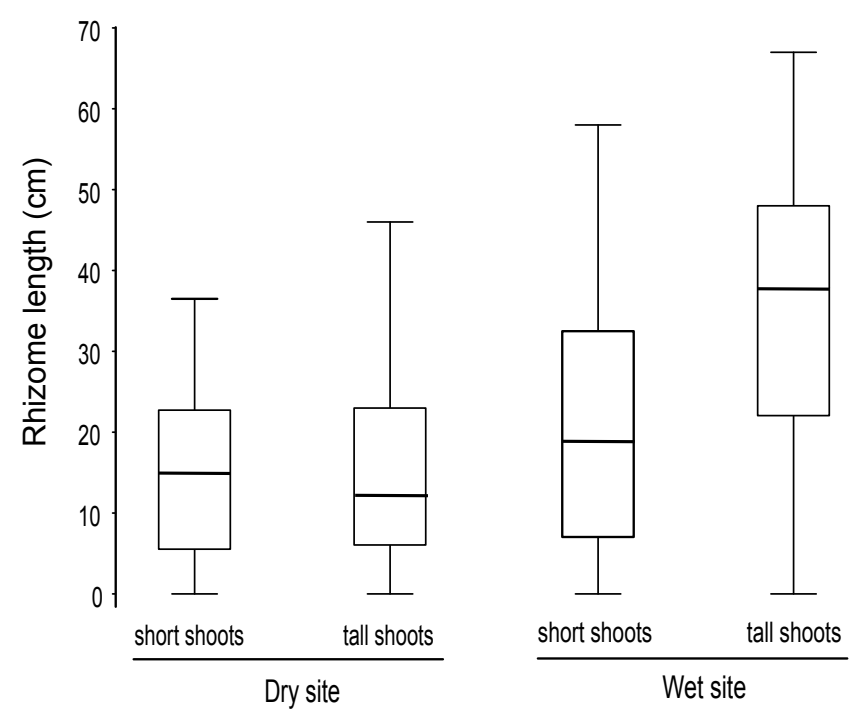

Fig. 4. Box and whisker plot of rhizome lengths. Short shoots means shoots shorter, tall shoots means shoots taller than average shoot height in that site. By this division, relatively tall and suppressed, relatively short shoots were compared in each site disregarding the average shoot size of sites

Although there were short rhizomes in both sites (Fig. 4), the average rhizome length was significantly higher in the wet site (log-rank test: $\mathrm{c}^{2}=4.66$, $p<0.001$; Gehan-Wilcoxon test: $\mathrm{W}=3.63, p<0.001$ ).

We found a significant difference between the two sites in the distributions of branching angles $\left(\mathrm{U}^{2}=0.1919, p \approx 0.045\right)$. But the significance of this small difference can probably be attributed to the relatively large sample size (there were 292 and 208 new rhizomes in the dry and wet site, respectively) rather than to any biological difference (Fig. 5).
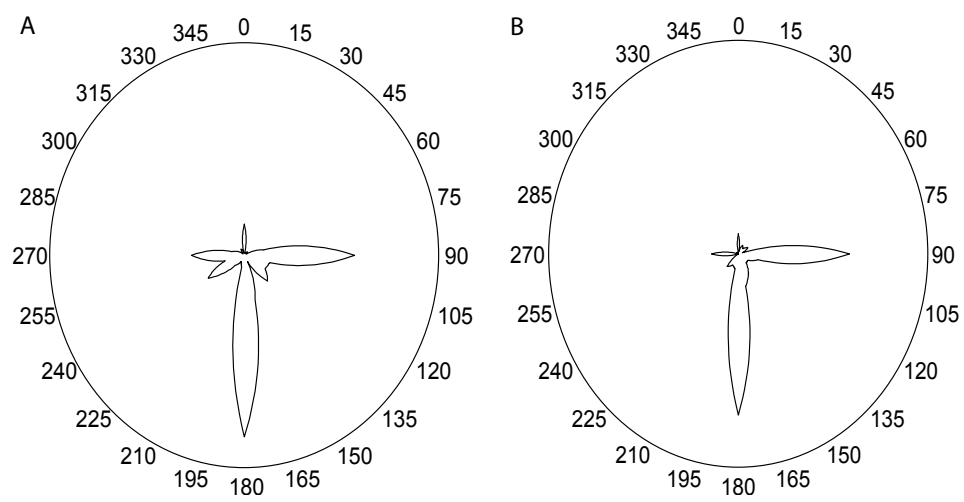

Fig. 5. Distribution of branching angles (angles between old and new rhizomes; see Figure 2) $(A=$ dry site, $B=$ wet site $)$ 
Table 2

Summary of the results. $<$ and $>$ indicate significant differences, while $\approx$ indicate that there were no significant difference

\begin{tabular}{lcccccc}
\hline & \multicolumn{2}{c}{ Between sites } & \multicolumn{3}{c}{ Within sites } \\
\cline { 2 - 6 } & dry site & wet site & \multicolumn{2}{c}{ dry site } & \multicolumn{2}{c}{ wet site } \\
\hline Shoot height & $<$ & & short & tall & short & tall \\
Rhizome number & $>$ & $<$ & & $<$ & \\
Rhizome length & $<$ & & $\approx$ & & $<$ & \\
\hline
\end{tabular}

\section{Within sites comparisons}

Taller shoots developed more rhizomes in both sites $\left(\mathrm{G}^{2}=14.75, p<0.01\right.$ in the dry site; $\mathrm{G}^{2}=15.97, p<0.01$ in the wet site; Fig. 6 ). In the wet site, the rhizomes of tall shoots were longer than the rhizomes of short shoots (log-rank test 5.26, $p<0.001$; Gehan-Wilcoxon test: $\mathrm{W}=4.83, p<0.001$; Fig. 4 ). In the dry site, there was no significant difference (log-rank test $0.82, p=0.2$; Gehan-Wilcoxon test: $\mathrm{W}=0.002, p=0.49$; Fig. 4 ).

\section{DISCUSSION}

\section{Variation in natural communities}

Both rhizome numbers and rhizome lengths were significantly different in the two habitats (Table 2). This confirms the results of earlier glasshouse

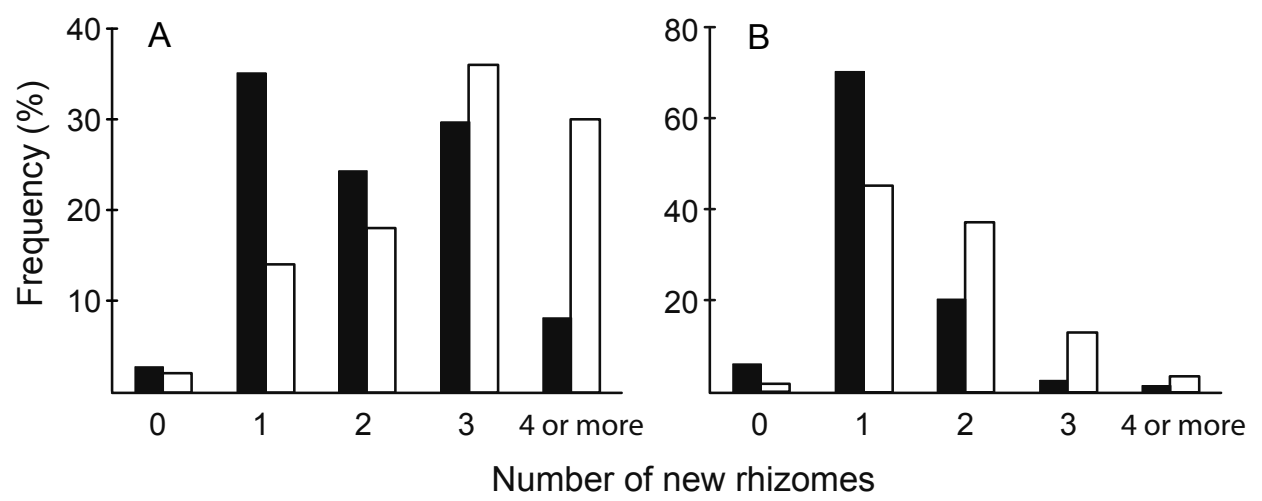

Fig. 6. Histogram of the rhizome number of short (filled bar) and tall shoots (empty bar) in the two sites. Short shoots means shoots shorter, tall shoots means shoots taller than average shoot height in that site. By this division, relatively tall and suppressed, relatively short shoots were compared in each site disregarding the average shoot size of sites $(\mathrm{A}=$ dry site, $\mathrm{B}=$ wet site) 
experiments: there is plasticity in the geometry of Solidago's rhizome system in natural conditions.

Cain $(1991,1994)$ pointed out that the long-term consequence of different rhizome lengths in terms of net displacement of the clone strongly depends on the distribution of branching angles. In our case, however, the distribution of branching angles proved to be constant.

\section{Possible explanations for the differences}

In the dry site, where the average shoot height was lower, shoots developed more rhizomes than in the wet site. On the other hand, within both sites, taller shoots developed more rhizomes (Table 2). This contradiction suggests that the difference between sites in rhizome number was "real" plasticity, not only a consequence of different sizes of above-ground shoots.

The two sites differed in the rhizome lengths of short vs. tall shoots. In the wet site, the rhizomes of taller shoots were longer. If the same trend existed in the dry site, too, this could have explained the differences between sites. In the dry site, however, rhizome length was not influenced by shoot height. Some other factors prevented tall shoots from developing long rhizomes. This factor may be, for example, the dense root system of coexisting species, which can mechanically restrict rhizome growth (cf. Schmid and Bazzaz 1990, 1992). Apical buds of developing rhizomes may hinder the initiations of new rhizomes. When the rhizome growth stops, for example because it is mechanically restricted, apical dominance decreases and new rhizomes can be initiated. This is a possible explanation to the higher number of rhizomes in the dry site.

\section{Consequences of the differences}

After establishment, Solidago propagates almost exclusively by rhizomes (Cornelius 1990). Thus, the number and length of rhizomes are very important life-history parameters, and the observed differences may have important consequences on the competitive ability:

(1) More intensive integration within genets in the dry site. - Comparing Solidago canadensis, S. gigantea and Aster spp., Schmid and Bazzaz (1987) found a negative correlation between average rhizome length and the level of within-genet integration. This rule may hold within a species, too, because transport is easier to shorter distances. According to the diversity of co-occurring species, the dry site was more heterogeneous. Integration among shoots decreases the effect of this heterogeneity on genet performance (Hartnett and Bazzaz 1985a). Thus, integration can be very advantageous in the dry site, whenever averaging of microhabitat conditions over more than one ramet is favourable. 
(2) Quick sprouting in the wet site. - In spring, new ramets obtain resources from the rhizomes. Large rhizomes may be able to support more rapid ramet growth. Quick sprouting may be relatively more advantageous in the wet site, where light is a major limiting factor. Earlier studies (Cain 1990, Goldberg 1988, Stoll et al. 1998) have shown that in the case of other Solidago species (S. altissima and S. canadensis), there is a positive correlation between parent rhizome length, ramet size, chance of survival and chance of flowering. Thus, it can be hypothesised that the production of long rhizomes is adaptively advantageous.

(3) Populations avoid overcrowding in the wet sites. - Meyer and Schmid (1999) suggested that "genets of Solidago altissima would prevent intraclonal crowding by producing longer but fewer rhizomes as they increased in size". If the ramets are not strongly integrated, then the number of rhizomes is decided at ramet rather than genet level. This mechanism would prevent not only intraclonal but also even intraspecific crowding. Earlier experiments (Hartnett and Bazzaz 1985b, Schmid et al. 1988) did not find any clear relationship between ramet density and rhizome structure. In our study, the density correlated positively with rhizome length and negatively with rhizome number. The comparison between short and tall ramets at the same site suggests that this is probably a consequence of mechanical restriction and not a mechanism to avoid overcrowding.

Which environmental clues may control the response of rhizomes to below-ground competition?

Schmid and Bazzaz (1992) suggested that "guerrilla" and "phalanx" species responded differently to competition. "Guerrilla" species tend to respond by decreased rhizome number and increased rhizome length, whereas "phalanx" species respond to competition by increased rhizome number and decreased rhizome length. Although, the term "guerrilla" and "phalanx" are always relative, Solidago species rather belong to the second group. They supposed that the most important effect of the competitors is the depletion of resources and this clue controls the response of rhizomes (Schmid and Bazzaz 1992). In experiments, fertilisation did not have any significant effect on the rhizome structure of Solidago (Schmid and Bazzaz 1992). In the same experiment, the type of competitor species had a significant effect (e.g. in the dense root mat of Poa, Solidago developed more but shorter rhizomes). It is possible that the morphological response in some rhizomatous "phalanx" species cannot be attributed to environmental clues (as supposed by Schmid and Bazzaz 1992) but mechanical restriction of rhizome growth. 


\section{Plasticity and invasiveness}

Ecologists interested in biological invasions have repeatedly attempted to answer the question: what sorts of traits are specific to invasive species (e.g. Fenesi and Botta-Dukát 2010, Kolar and Lodge 2001)? Most authors concentrated on the "average" of life history traits and variation of traits within species has usually been neglected (except in Ashton and Mitchel 1989). Plasticity can be of great importance, because the same property may be advantageous in one habitat but disadvantageous in another habitat. Solidago gigantea occurs in very different habitats, and its morphological plasticity may facilitate its wide distribution and high invasiveness.

\section{CONCLUSIONS}

Although only two sharply different habitats were compared in this study, these sites were chosen to represent two typical habitats of Solidago. Thus, in spite of autocorrelation of data, the results allow to say that there is plasticity of below-ground organs in natural conditions and to generate well-established hypotheses on its causes and consequences. Of course, these hypotheses have to be tested by experiments and further field studies are needed to evaluate the relationship between habitat and rhizome morphology in detail.

Acknowledgements - We are grateful to István Szabó, who showed us first this interesting situation, to Júlia Tamás, Barbara Lhotsky, Zsuzsa Hayek and Sándor Barabás for assistance in the field work, to Beáta Oborny, Miklós Kertész, Sándor Bartha and György KröelDulay for their helpful suggestion and to Réka Aszalós for drawing figures.

\section{REFERENCES}

Almádi, L., Botta-Dukát, Z., Dancza, I. and Szabó, I. (1997): A Solidago gigantea Ait. reproduktív hajtásrendszerének (tarack, virágzatrendszer) morfológiája. (Über die Morphologie der Spross- und Auslauferentwicklung von Solidago gigantea). - Kitaibelia 2: 321-322.

Alpert, P. (1995): Does clonal growth increase plant performance in natural communities? - Abstracta Botanica 19: 11-16.

Ashton, P. J. and Mitchel, D. S. (1989): Aquatic plants: patterns and modes of invasion, attributes of invading species and assessment of control programmes. - In: Drake, J. A., Mooney, H. A., di Castri, F., Groves, R. H., Kruger, F. J., Rejmánek, M. and Williamson, M. (eds): Biological invasion. A global perspective. John Wiley and Sons, Chichester, pp. 111-154. 
Balogh, L., Botta-Dukát, Z. and Dancza, I. (2003): What kind of plants are invasive in Hungary? - In: Child, L. E., Brock, J. H., Brundu, G., Prach, K., Pyšek, P., Wade, P. M. and Williamson, M. (eds): Plant invasions: ecological threats and management solutions. Backhuys Publishers, Leiden, The Netherlands, pp. 131-146.

Bell, A. D. (1979): The hexagonal branching pattern of rhizomes of Alpinia speciosa L. (Zingiberaceae). - Ann. Bot. 43: 209-223.

Botta-Dukát, Z. (1994): Classification of Giant goldenrod (Solidago gigantea Ait.) stands on urban habitats around Keszthely town. - In: Mochnacky, S. and Terpó, A. (eds): Proceedings of International Conference Anthropization and Environment: Flora and Vegetation, pp. 5-8.

Botta-Dukát, Z. and Dancza, I. (2008): Giant and Canadian goldenrod (Solidago gigantea Ait., S. canadensis L.). - In: Botta-Dukát, Z. and Balogh, L. (eds): The most important invasive plants in Hungary. Institute of Ecology and Botany of the Hungarian Academy of Sciences, Vácrátót, pp. 167-177.

Cain, M. L. (1990): Models of clonal growth in Solidago altissima. - J. Ecol. 78: 27-46. http:// dx.doi.org/10.2307/2261034

Cain, M. L. (1991): When do treatment differences in movement behaviors produce observable differences in long-term displacements? - Ecology 72: 2137-2142. http://dx.doi. org/10.2307/1941565

Cain, M. L. (1994): Consequences of foraging in clonal plant species. - Ecology 75: 933-944. http://dx.doi.org/10.2307/1939417

Callaghan, T. V., Carlsson, B. Å., Jónsdóttir, I. S., Svensson, B. M. and Jonasson, S. (1992): Clonal plants and environmental change: introduction to the proceedings and summary. - Oikos 63: 341-347. http://dx.doi.org/10.2307/3544959

Coleman, J. S., McConnaughay, K. D. M. and Ackerly, D. D. (1994): Interpreting phenotypic variation in plants. - Trends Ecol. Evol. 9: 187-191. http://dx.doi.org/10.1016/01695347(94)90087-6

Cornelius, R. (1990): The strategies of Solidago canadensis L. in relation to urban habitats. III. Conformity to habitat dynamics. - Acta Oecol. 11: 301-310.

Dancza, I. and Botta-Dukát, Z. (2000): Historical and recent data on the distribution of North American Solidago species (Solidago gigantea, S. canadensis) in Hungary. - In: Zajac, A., Zajac, M. and Zemanek, B. (eds): Phytogeographical problems of synanthropic plants. Institute of Botany, Jagiellonian University, Cracow.

Fenesi, A. and Botta-Dukát, Z. (2010): Do short-lived and long-lived alien plant species differ regarding the traits associated with their success in the introduced range? - Biol. Invasions 12: 611-623. http://dx.doi.org/10.1007/s10530-009-9468-6

Goldberg, D. E. (1988): Response of Solidago canadensis clones to competition. - Oecologia 77: 357-364. http://dx.doi.org/10.1007/bf00378042

Hartnett, D. C. and Bazzaz, F. A. (1985a): The integration of neighbourhood effects by clonal genets in Solidago canadensis. - J. Ecol. 73: 415-427. http://dx.doi.org/10.2307/2260484

Hartnett, D. C. and Bazzaz, F. A. (1985b): The regulation of leaf, ramet and genet densities in experimental populations of the rhizomatous perennial Solidago canadensis. $-J$. Ecol. 73: 429-443. http://dx.doi.org/10.2307/2260485

Kolar, C. S. and Lodge, D. M. (2001): Progress in invasion biology: predicting invaders. Trends Ecol. Evol. 16: 199-204. http://dx.doi.org/10.1016/s0169-5347(01)02101-2

Kroon, H. de and Hutchings, M. J. (1995): Morphological plasticity in clonal plants: the foraging concept reconsidered. - J. Ecol. 83: 143-152. http://dx.doi.org/10.2307/2261158 
Leakey, R. R. (1981): Adaptive biology of vegetatively regenerating weeds. - Adv. Appl. Biol. 6: 57-90.

Meyer, A. H. and Schmid, B. (1999): Experimental demography of the old-field perennial Solidago altissima: the dynamics of the shoot population. - J. Ecol. 87: 17-27. http:// dx.doi.org/10.1046/j.1365-2745.1999.00315.x

Moesz, G. (1909): Nehány bevándorolt és behurczolt növényünk. - Bot. Közlem. 8: 137-147.

Noble, J. C., Bell, A. D. and Harper, J. L. (1979): The population biology of plants with clonal growth I. The morphology and structural demography of Carex arenaria. $-\mathrm{J}$. Ecol. 67: 983-1008. http://dx.doi.org/10.2307/2259224

Oborny, B. (1994): Growth rules in clonal plants and environmental predictability. A simulation study. - J. Ecol. 82: 341-351. http://dx.doi.org/10.2307/2261302

Prach, K. and Pyšek, P. (1994): Conal plants - what is their role in succession? - Folia Geobot. Phytotax. 29: 307-320. http://dx.doi.org/10.1007/bf02803803

Pyke, D. A. and Thompson, J. N. (1986): Statistical analysis of survival and removal rate experiments. - Ecology 67: 240-245. http://dx.doi.org/10.2307/1938523

Pyšek, P. (1997): Clonality and plant invasions: can a trait make a difference? - In: Kroon, H. de and van Groenendael, J. (eds): The ecology and evolution of clonal plants. Backhuys Publishers, The Netherlands, pp. 405-427.

Richardson, D. M., Pyšek, P., Rejmánek, M., Barbour, M. G., Panetta, F. D. and West, C. J. (2000): Naturalization and invasion of alien plants: concepts and definitions. $-D i-$ versity and Distributions 6: 93-107. http://dx.doi.org/10.1046/j.1472-4642.2000.00083.x

Schmid, B. and Bazzaz, F. A. (1987): Clonal integration and population structure in perennials: effects of severing rhizome connections. - Ecology 68: 2016-2022. http://dx.doi. org/10.2307/1939892

Schmid, B. and Bazzaz, F. A. (1990): Plasticity in plant size and architecture in rhizomederived vs. seed-derived Solidago and Aster. - Ecology 71: 523-535. http://dx.doi. org/10.2307/1940306

Schmid, B. and Bazzaz, F. A. (1992): Growth responses of rhizomatous plants to fertilizer application and interference. - Oikos 65: 13-24. http://dx.doi.org/10.2307/3544882

Schmid, B., Puttick, G. M., Burgess, K. H. and Bazzaz, F. A. (1988): Clonal integration and effects of simulated herbivory in old-field perennials. - Oecologia 75: 465-471. http:// dx.doi.org/10.1007/bf00376953

Sebsen, K. P. and Thorne, B. L. (1985): Coexistence of clones, clonal diversity, and the effects of disturbance. - In: Jackson, J. B. C., Buss, L. W. and Cook, R. E. (eds): Population biology and evolution of clonal organisms. Yale University Press, New Haven, pp. 357-396.

Shorina, N. I. and Smirnova, O. V. (1985): The population biology of ephemeroids. - In: White, J. (ed.): The population structure of vegetation. Dr. W. Junk Publishers, Dordrecht, pp. 225-240.

Slade, A. J. and Hutchings, M. J. (1987a): The effects of light intensity on foraging in the clonal herb Glechoma hederacea. - J. Ecol. 75: 639-650. http://dx.doi.org/10.2307/2260196

Slade, A. J. and Hutchings, M. J. (1987b): The effects of nutrient availability on foraging in the clonal herb Glechoma hederacea. - J. Ecol. 75: 95-112. http://dx.doi. org/10.2307/2260538

Sokal, R. R. and Rohlf, F. J. (1981): Biometry. The principles and practice of statistics in biological research. - Freeman, New York.

Stoll, P., Egli, P. and Schmid, B. (1998): Plant foraging and rhizome growth patterns of Solidago altissima in response to mowing and fertilizer application. - J. Ecol. 86: 341-354. http://dx.doi.org/10.1046/j.1365-2745.1998.00263.x 
Sutherland, W. J. and Stillman, R. A. (1988): The foraging tactics of plants. - Oikos 52: 239244. http://dx.doi.org/10.2307/3565196

Szabó, I., Botta-Dukát, Z. and Szeglet, P. (1998): A vegetáció kis léptékü, korai változásainak jelentősége a Kis-Balaton természetvédelmi biológiai monitorozásában. (Smallscale early changes of the vegetation used for nature-protection biomonitoring of Kis-Balaton). - Term.véd. Közlem. 7: 75-88.

Thompson, J. D. (1991): The biology of an invasive plant. - BioScience 41: 393-401. http:// dx.doi.org/10.2307/1311746

Török, K., Botta-Dukát, Z., Dancza, I., Németh, I., Kiss, J., Mihály, B. and Magyar, D. (2003): Invasion gateways and corridors in the Carpathian Basin: biological invasions in Hungary. - Biol. Invasions 5:349-356. http://dx.doi.org/10.1023/b:binv.0000005570.19429.73

Weber, E. (1998): The dynamics of plant invasions: a case study of three exotic goldenrod species (Solidago L.) in Europe. - J. Biogeogr. 25: 147-154. http://dx.doi.org/10.1046/ j.1365-2699.1998.251119.x

Werner, P. A., Gross, R. S. and Bradbury, I. K. (1980): The biology of Canadian weeds: 45. Solidago canadensis L. - Can. J. Plant Sci. 60: 1393-1409. http://dx.doi.org/10.4141/ cjps80-194

Zar, J. H. (1999): Biostatistical analysis. - Prentice and Hall, Upper Saddle River, NY, US. 